\title{
定置漁具のレーダー映像についてーI
}

ーシイラつけ探知障害についての考察 —

\author{
神鳥 昭 \\ Radar Echoing Characteristics from the Floating Part of \\ Fishing Gear-II. \\ - Radar Detection of Dolphin Bamboo Shelter, with Reference to \\ its Obstructions -
}

\section{A. Kandori}

\begin{abstract}
The previous paper of this series had revealed that the marine radar had small target but was available for detection of the dolphin bamboo shelter under the ordinary meteorological and oceanographic conditions. But the navigator should be aware of the critical conditions of the radar to pick up the target. This is due to the following possibility: They are frequently obliged to detect even small objects such as small fishing craft and floating part or marker of the fishing gears settled. These will usually have the target of small equivalent echoing area, consequently give fluctuating echo weaker than the rain or sea clutter echos. The above-mentioned facts meant that it is hard to neglect of the possibility of mis-detecting the small objects in these obstructive clutters. In addition, the detection range of target will suffer considerably from the reduction of the projected area of the target or the effect of the shadow sector due to the ships structure.
\end{abstract}

The present paper dealt with the radar detection of the dolphin bamboo shelter in relation to either the relative direction of the shelter or the obstruction due to rain and sea clutters or to shadow sector.

\section{1.まえがき}

夏期日本海の船舶の航行する沖合海面には多数のシイラづけ定置漁具が敷設される。これらの シイラづけは，夜間・狭視界時等に航行船舶の接触に起因すると思われる流失事故がきわめて多 い。これらの事故を防止するため，船舶に装備したレーダーを使用する場合のシイラづけ探知の 可能性について前報〔1]で報告した。

前報では晴天・海上平榣時のレーダ一観測結冞について考察したが，シイラづけは小型目標物 であるため，気象・海象状態が悪化票れれ種々の障害を5けて探知距離は減少し，場合によつて 探知不能となることも考えられる。探知障害の要因としては，降雨・海面反射・シイラづけの向 きによる反射指向特性・船体構造物による電波の遮蔽等が考えられるので，各々の場合について 
観測・調查し、レーダー観測によるシイラゔけ挆知の限界について考察した。

\section{Rain clutter による探知障容}

降雨による探知障害は，雨滴による電波の吸収と反射が考えられ るが，前者はきわめて小さく，障害要因の主たるものは後者であ る。雨滴からの反射映像はPPI 上をマスクして，目標映像の識別を 困難にする。雨の強さは表 1 に示す 5 段階に分けられており，降雨 強度と rain clutter との間には相関があるものと考えられる。しか し多くの雨は強くなつたり，弱くなつたりして降り続くのが普通

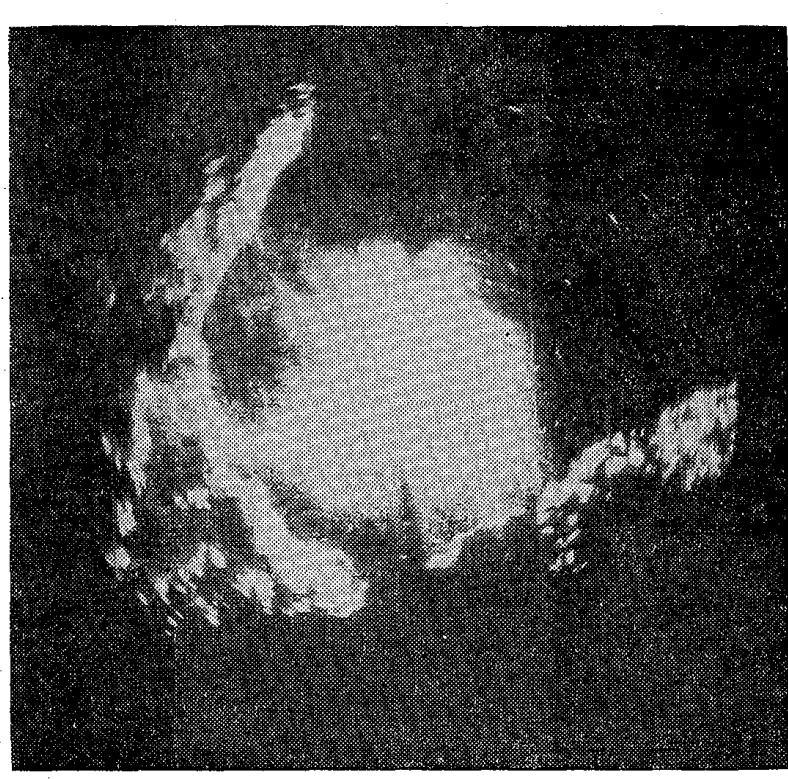

図 1 (a) Suppressor 2

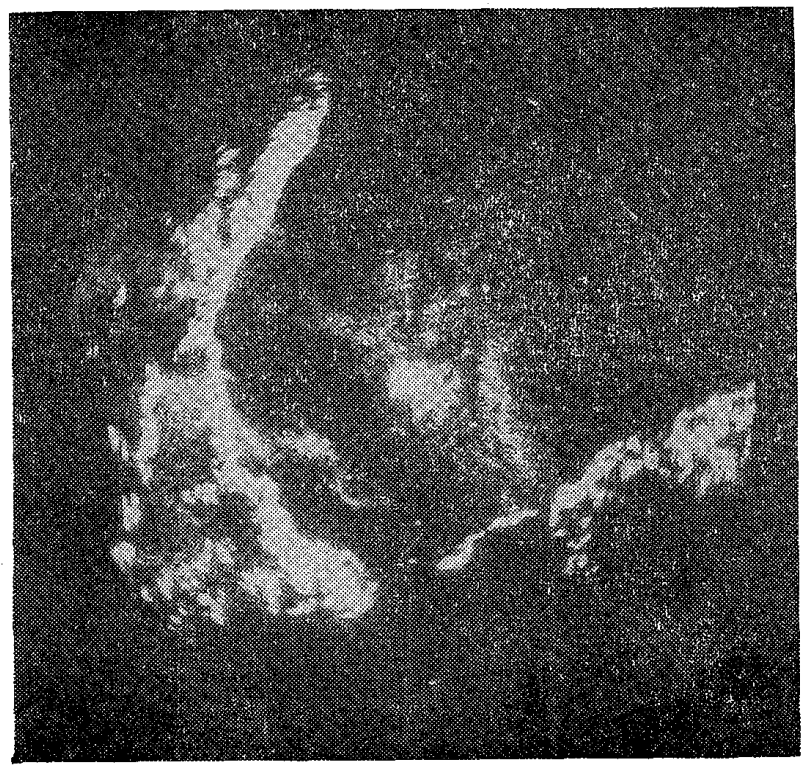

図 1 (b) Suppressor 6
表 1 降雨 強度

\begin{tabular}{|c|c|}
\hline 雨の強さ & $\begin{array}{l}\text { 雨 量強度 } \\
(\mathrm{mm} / \mathrm{min})\end{array}$ \\
\hline 特に弱い雨 & 0.02 以下 \\
\hline 弱 い：雨 & $0.02 \sim 0.05$ \\
\hline 並 雨 & $0.05 \sim 0.25$ \\
\hline 強 $、$ 雨 & $0.25 \sim 1$ \\
\hline 特に強い雨 & 1 半以上 \\
\hline
\end{tabular}
で，同一降雨域内 でも降雨強度は必 ずしも一様でない といわれている。 同一降雨域内の降雨状態を調べるためレーダ— 観測を行ないその結果を図 1 に示す。温帯性低 気压による持続性降雨で, 比較的安定した降り 方をしていると思われる時期を選び PPI 上 にそのrain clutter を観察し（図1・a），次いで suppressorを徐々に上げて, rain clutter 消滅の 状態加ら同一降雨域内の降雨状況を推定した。 図1(a)の場合は rain clutter 沬半径 5 浬の範囲に 及び，この範囲内は一様に雨の反射像でマスク されているが，この範囲外にある左げん正横の 淡路島・後方の友方島および $0^{\circ} \sim 90^{\circ}$ 方向の航

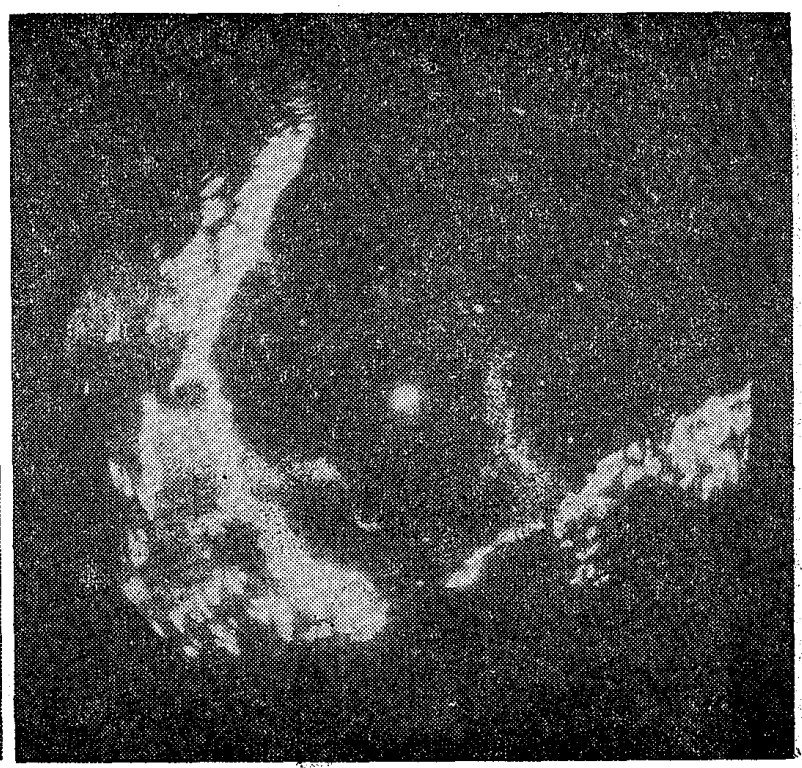
図 1.レーダー観測による同一雨城内の降雨状態

（注）観測日時 1963年 3 月24日 1342 観測位置 大阪湾 $\left(31^{\circ}-21.4^{\prime} . \mathrm{N}, 135^{\circ}-00.5^{\prime} \mathrm{E}\right)$ 使用レンジ 10浬 
行船舶は, 鮮明な映像として認められる。これは降雨によるレーダー電波の吸収・減衰がきうめ て小さいことを裏づけるものと思われる。 suppressor を上げた(b)・(c)では rain clutter の消滅状 態は，必ずしもレーダー空中線からの距離に比例せず，同一降雨域内でも降雨強度は全く一樣で ないことが推定できる。

シイシづけのレーダー探知について考える場合, その範囲は半径 2 浬程度の狭い範囲であるか ら，レーダー空中線とシイラづけは同一降雨域内にあり，かつこの範囲内では降雨強度は一様で あると考えても差支えないものと思われる。シイラゔけとレーダー空中線が同一降雨域内にある 場合, シイラづけ映像が rain clutter によつて識別不能となる降雨強度の限界について受信電力 比から考察する。

レーダー波の雨滴からの反射㧤よび降雨強度と反射波の受信電力との関係については，気象学 の分野で多くの実験・研究結果が報告 [2]・[3]・[4]・[5]されているので，これを参考に し舶用レーダーの特性を考慮して雨の反射強度を計算した。レーダ一波の全ビームが雨滴で遮断 されたときの受信電力は次式で与えられる[6]。

$$
\overline{P_{r}}=\left(\frac{\pi^{5}}{72} \frac{P_{t} A_{p}^{2} \theta \phi h}{\lambda^{6}}\right)\left|\frac{m^{2}-1}{m^{2}+2}\right|^{2} \frac{Z}{r^{2}}
$$

ここで $P_{r}$ 涭信電力 $(\mathrm{w}), P_{t}$ 送信電力 $(\mathrm{w}), A_{P}$ 空中線開口面積 $\left(\mathrm{m}^{2}\right), \theta$ 水平ビーム幅 $(\mathrm{rad})$, $\phi$ 垂直ビーム幅 $(\mathrm{rad}),$.$h パルス長 (\mathrm{m}), \lambda$ 波長 $(\mathrm{mm}), m$ 複素屈折率, $Z$ 雨のレーダー反 射因子 $\left(\mathrm{mm}^{6} \mathrm{~m}^{-3}\right), r$ 雨滴とレーダー空中線の距離 $(\mathrm{m})$ である。

反射係数 $\left|\left(m^{2}-1\right) /\left(m^{2}+2\right)\right|^{2}$ はレーダーの波長と温度による関数であるが， $3 \mathrm{~cm}$ 波の場合 温度による変化は小さく 0.93 として差支えない [7]。また反射因子 $Z\left(\mathrm{~mm}^{6} \mathrm{~m}^{-3}\right)$ と降雨強度 $R(\mathrm{~mm} / \mathrm{h})$ との関係はかなり複雑であるが，温帯性の降雨については $Z=200 R^{1.60}$ 夯適当とされて いる [8]。次に空中線利得を $G$, 空中線の実効面積を $A_{e}$ とすると, $A_{e}=G \lambda^{2} / 4 \pi, G=8 \pi / 3 \times$ $A_{P} / \lambda^{2}$ なる関係があるので, 表 1 の降雨強度 $R^{\prime}(\mathrm{mm} / \mathrm{min})$ について, その受信電力を考える場 合(1)式は次のようになる。

$$
\overline{P_{r}}=\frac{\pi^{5} P_{t} A_{e}^{2} \theta \phi h \times 0.93 \times 200}{32 \times \lambda^{6}} \frac{\left(60 R^{\prime}\right)^{1.60}}{r^{2}}
$$

(2)式に実験に使用した JMA-103 型レーダーの 諸元 $P_{t}=3 \times 10^{4}(\mathrm{w}), \theta=$ 0.026 (rad.); $\phi=0.332$ (rad.), $h=120(\mathrm{~m}), A_{e}=$ $0.4\left(\mathrm{~m}^{2}\right), \lambda=32(\mathrm{~mm})$ を 入れ，各降雨強度 $\left(R^{\prime}\right.$ $\mathrm{mm} / \mathrm{min}$ 汢各クラスの 中央值をとる）について 受信電力を計算した。な お舶用レーダーの場合， 垂直ビームの下半分は海 面でカツトされるため受 信電力は半減するものと し，得られた受信電力を

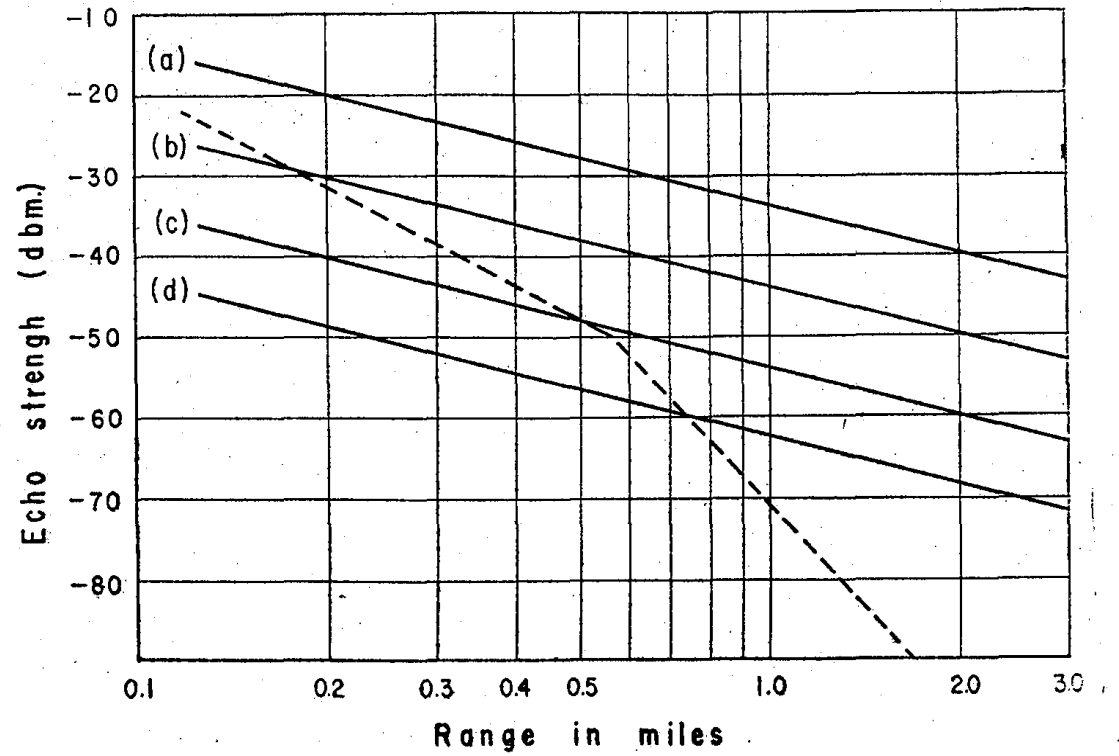

図 2 雨滴およびシイラゔけの反射強度

(注) (a) 強、雨 $\quad$ (b) 並 雨 $\quad$ (c) 弱、雨 (d) 特に弱、雨 ……ジィラづけ 
$\mathrm{dbm}$ 単位に換算して，レーダー空中線からの距離による雨の反射強度の変化を図 2 に示す。

次にシイラゔけ反射強度については測定できなかつたので，シイラづけの最大探知距離および 有効高さから推定した。レーダーの最小受信感度は, おおよそシイラづけ映像が PPI 上から消失 するときの受信電力で示され，一般に最小受信感度はー80 - $85 \mathrm{dbm}$ ，また受信電力が距離のー4 乗に比例する区域から-8 乗に比例する区域への移行点は，一65 dbm 付近といわれているが目標 物により多少の差異がある。目標物の有効面積・有効高さにおいて, シイラづけに近い伝馬船に ついて受信強度の実測結果が報告 [9]されているので, これを参考にしシイラつけの最小受信感 度を $-80 \mathrm{dbm}$ ，移行点を $-50 \mathrm{dbm}$ と推定した。この推定にもとづくシイラづけの受信電力と距 離との関係を図 2 に点線で示した。この図から降雨中でシイラづけをレーダー探知できる限界注 特に弱い雨で0.7浬, 弱い雨で注0.5浬と認められ, この限界内では, suppressor を最良の状態に 調整すれば rain clutter を抑制して必要なシイラゔけ映像のみをPPI 上に残すことができる。ま た並雨以上の強い雨では suppressor を如何に調 整してもシイラつけをレーダーで探知すること はほとんど不可能であると䓅えられる。

\section{Sea clutterによる探知障害}

PPI 上の sea clutter の範囲は波高・海水の飛沫就よび波浪の走向とレーダービームのなす角 によつて決まるものと考えられる。 sea clutter の最大要因である波高と sea clutter との関係を 直接求めたいと考えたが，船上での波高目視観測は相当の熟練者でないと正確を期し難い。一方 風浪の状態は風速・吹送距離・風の継続時間によつて決まるが，最も関連性の大きいのは風速で ある。日本海に㧍ける風速と風浪の関係については調査結果が発表[10]されており，風速と波高 との閒には対忘が認められるので，さらに風速と PPI 上の sea clutter との間にも相関があるも のと考えられる。

図 3 は1963年 7 月日本海 方面を漁業練習船天鹰丸 （旧）で航海し観測した風速 とPPI 上の sea clutter と の関係を示す。観測に使用 したレーダーの調整はシイ ラら゙け探知実験に使用した ものと同一条件とし，2浬 レンジを使用したが sea clutter が2 2 浬以上に及ぶ ときは 5 浬レンジに切替え た。図 3 では風速に対する sea clutter の範囲(風上側) はかなりのばらつきがみら れるが，相互間には相関が

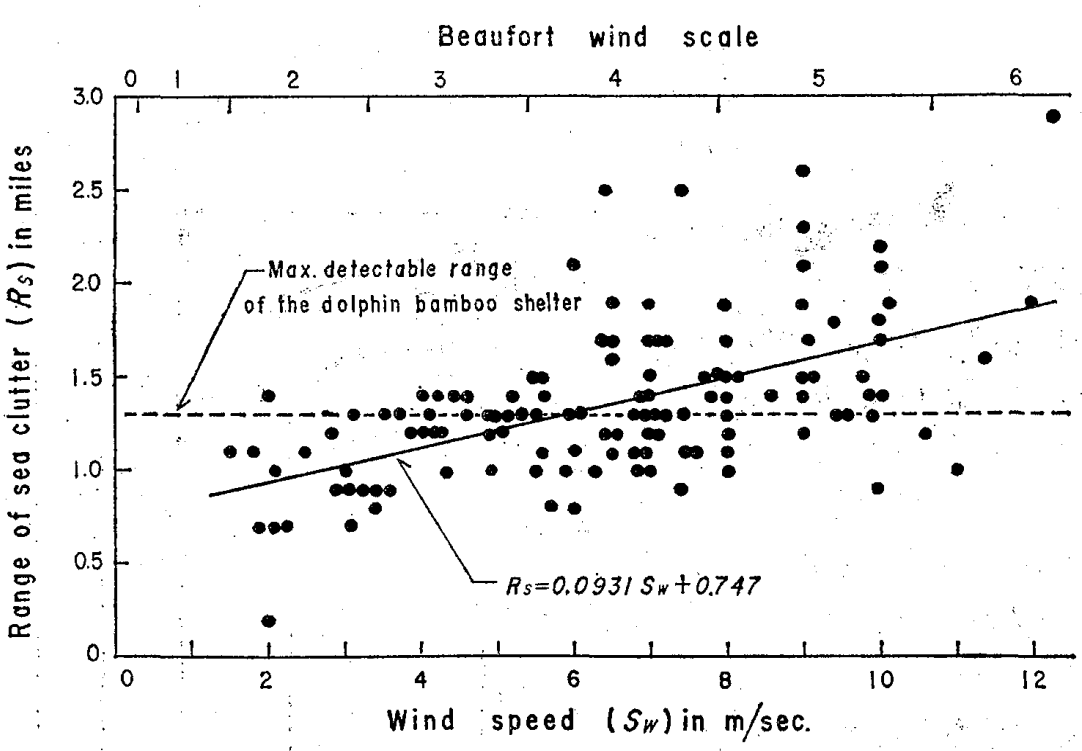

図 3 PPI 上の sea clutter の範囲と風速との関係 認められる。

次に晴天・海上平穏時のシイラぶけのレーダー最大探知距離は1.3浬である[11]。しかし海況が 変れば探知距離も多少変化することが考えられるが,ここではシイラづけの最大探知距離を 1.3 浬 として, sea clutter が PPI 上をマスクすることによりシイラづけのレーダー探知が不能となる限 
界風速を推定すると，図 3 から $5.9 \mathrm{~m} / \mathrm{sec}$ を得る。したがつて風速 $5.9 \mathrm{~m} / \mathrm{sec}$ (ビュー゙フオート風 力階級で 4 ) 采では suppressor を適当に調整すれば sea clutter を抑制してシイラヴけを PPI上 に探知できるが， $5.9 \mathrm{~m} / \mathrm{sec}$ 以上の風速では.suppressor を如何に調整してもシイラゔけのレーダ 一探知注不可能と考光ら机る。

\section{4. シイラづけの向きとその探知距離の変化}

シイラづけは長さ $10 \mathrm{~m}$ 余の大竹十数本をイカダ型に束䄈たむので細長い形状をしているため, 長い辺に対するレーダービームの入射角度が探知距離に影響するものと考えられる。シイラづけ の碇綱はつけの一端にとりつけられているので，海潮流の影響をうけて，シイラつけはとて流線 に沿ってほぼ同一方向を向く。したがつてシイラづけ定置海面を航行して，レーダーでこれを探 知する場合レーダー空中線からみるシイラづけの所在方向によつて，シイラゔけの長い辺に対す るレーダービームの入射角は異なる。こ の入射角の差異が探知距離に及ぼす影響 度を前報の観測結果を使用して解析す る。

観測結果を発見・消失時の方向・距離 によつてプロツトしたのが図 4 である。 この図から船を基準としたシイラづけの 所在方向によつて探知距離に差異がある むのか，正確に判断することは困難であ るから確率的に考察する。先ず発見・消 失時のものに大別し，さらに図 4 に示す ように方向別に $P_{1}$. (観測番号 5, 10, $19,20,24), P_{2}(3,4,9,13,15$, $17,23), P_{3}(1,7,12,14,16,22$, $25,26), P_{4}(6,11,18), P_{5}(2,8$, 21), $P_{1}^{\prime}(5,7,10,19,20,23,24)$, $P_{\square}^{\prime}(1,12,14,16,22,25,26)$, $P_{3}^{\prime}(3,4,9,11,13,17), P_{4}^{\prime}(2$.

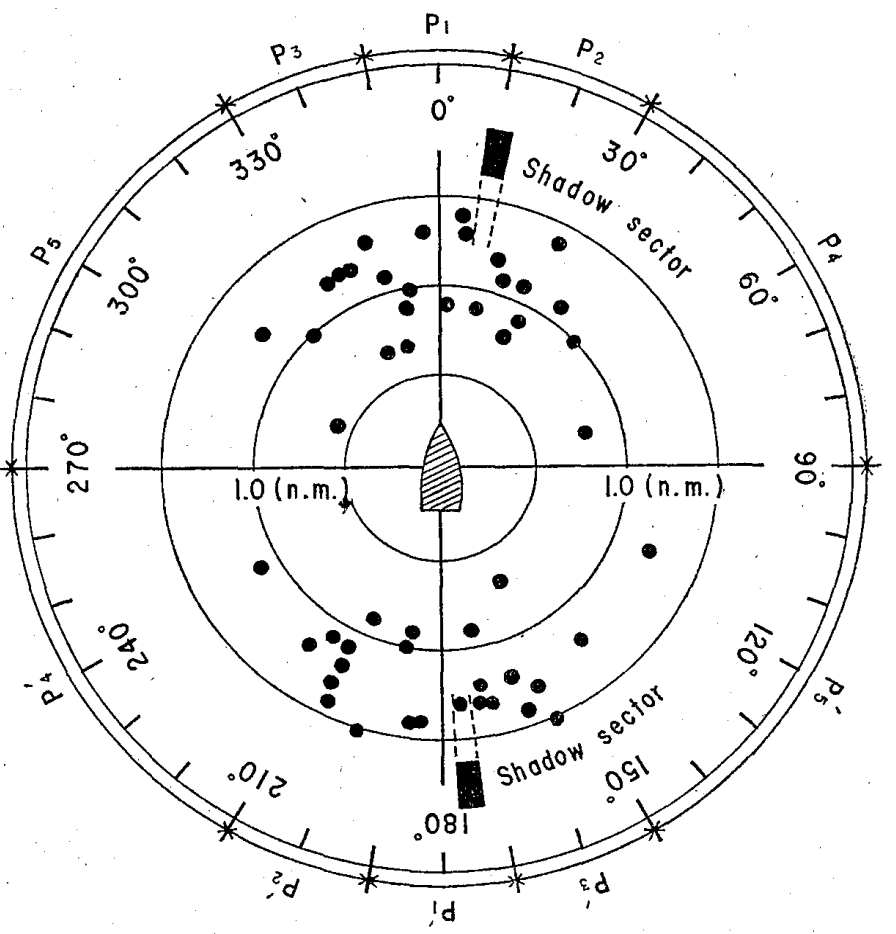

図 4 シイラうけ発見・消失時の船からの相対位置

表 2 分散 分析表

(a) 発見の場合

\begin{tabular}{|c|c|c|c|}
\hline 要 因 & $S \quad S$ & $D F$ & $M S$ \\
\hline$P$ & 0.0354 & 4 & 0.0088 \\
\hline$B_{(P)}$ & 0.2234 & 21 & 0.0106 \\
\hline$P B$ & 0.2588 & 25 & \\
\hline
\end{tabular}

$$
\begin{aligned}
F_{S}= & \frac{0.0088}{0.0106}=0.830 \\
& F_{21}^{4}(0.05)=2.84 \\
\therefore \quad & F_{s}<F_{21}^{4}
\end{aligned}
$$

\begin{tabular}{|c|c|c|c|}
\hline 要 因 & $S \quad S$ & $D F$ & $M S$ \\
\hline$P$ & 0.0110 & 4 & 0.0028 \\
\hline$B_{(P)}$ & 0.2664 . & 20 & 0.0133 \\
\hline$P B$ & 0.2774 & 24 & \\
\hline
\end{tabular}

（b）消失の場合

$$
\begin{gathered}
F_{S}=\frac{0.0028}{0.0133}=0.211 \\
F_{20}^{4}(0.05)=2.87 \\
\therefore \quad F_{S}<F_{20}^{4}
\end{gathered}
$$


$8 ， 21) ， P_{5}^{\prime}(6 ， 18)$ に分類する。なお確率的に考察するためには，対称となる量が正規型でな ければならないので探知距離Rは $\log (2.0-R)$ に変換し分散分析（表 2$)$ すると，5\%の危険率 で有意でなく，シイラづけの向きによるレーダ一探知距離の差異は認みられない。

シイラづけは不規則な形状をしているにもかかわらず，その反射指向性が認められないのは， 主として水面上の高さがきわめて低い（0.2〜0.3m）ためと考えられる。

\section{Shadow sector による探知障害}

船体の上部構造物特にマストはレーダー電波を遮つて影を作り，この shadow sector は目標物 の探知に障害があるといわれている。

この実験に使用したレーダー空中線と船体構造物の配置関係から shadow sector を推定できる

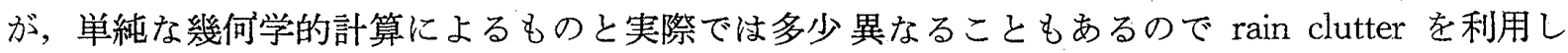
て shadow sector を確認した（図 5 )。この図から， shadow sector は右げん船首の $8^{\circ} \sim 12^{\circ}$ と右 げん後方の $173^{\circ} \sim 177^{\circ}$ にあることがわかる。 いずれもマストが原因であり配置関係から計算 したものとよく一致する。

この shadow sector がシイラづけ探知に及ぼ す影響を1963年 7 月 20 日能登沖のシイラづけ探 知実験で観察した。右げん船首方向に発見した シイラづけ映像は，それぞれ 1.0 浬と 0.8 浬で輝 度がおち， shadow sector による障害が認めら れたが，ヨーイングもあり， shadow sector の 影響を詳しく観察することができなかつた。船 体構造による shadow sector が小型目標物のレ ーダー探知に及ぼす影響については，今後さら に多くの資料を得て検討したい。

\section{6. む す び}

近時舶用レーダーは広く普及し, 安全運航に 不可欠の計器となりつつあるが，レーダーが目 標物をPPI上に探知・識別する能力には限界が ある。

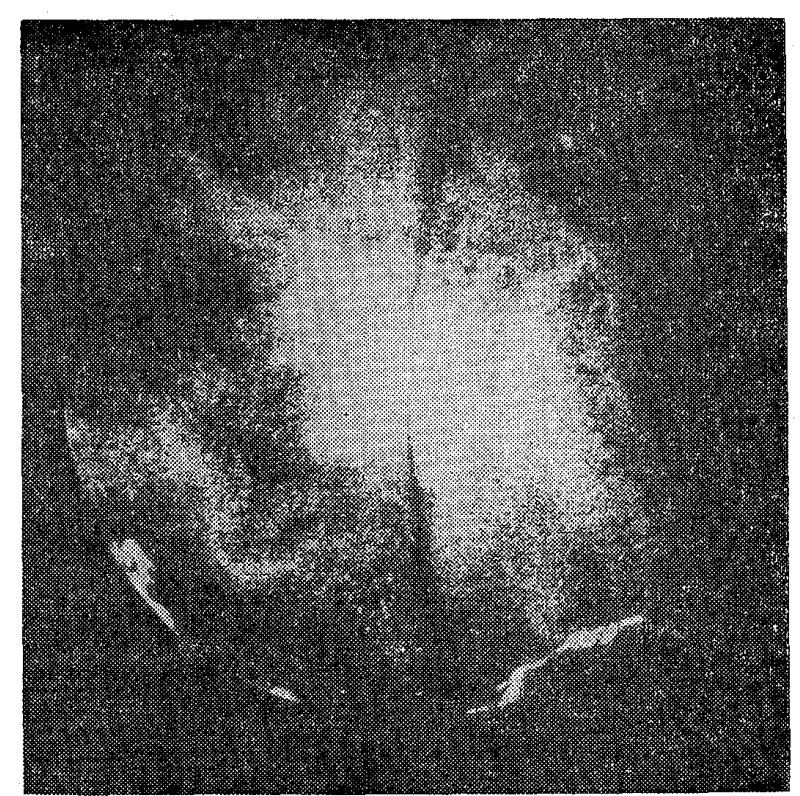

図 5.マストによる Shadow Sector

(注)観测日時 1963 年 3 月24日 1340 観 測 位置 大阪湾 $\left(31^{\circ}-21.4^{\prime} \mathrm{N}, 135^{\circ}-00^{\prime} . \mathrm{SE}\right)$ 使用レンジ 5 浬

ここでは日本海の沖合海面に敷設される小型目標物のシイラゔけ漁具について, rain clutter sea clutter および目標物の反射指向特性・船体上部構造物による shadow sector が, シイラつけ 探知に及ぼす影響について実験・考察した。

結果を要約すると炊のと㧍りである。

(1) Rain clutter による障害は，並雨以上の強い雨でシイラづけ探知をほとんど全面的に不可 能とする。また弱い雨・特に弱い雨でも，それぞれ 0.5 浬拉よび 0.7 浬を限度として以遠のシイ ラゔけは探知できない。

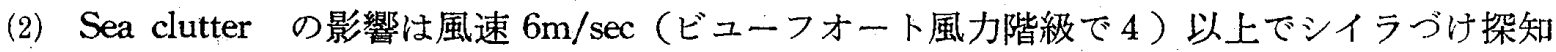
を不可能とする。

(3) シイラゔけの向きによる探知距離の差は認められない。 
(4) マストによる shadow sector が認められたがここの shadow sectur がシイラうけ探知に及 ぼす障㕩については十分な資料が得られなかつた。

終りに種々御助言をいただいた本校前田弘博士，気象関係の諸文献を貸与下さつた下関地方気 象台瓜生健治技術課長，実験に御協力下さつた旧天鷹丸士官各位に対し厚くお礼を申しあげます。

参 考 文 献

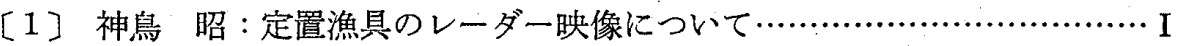

日本航海学会誌， 32 (1964) p. $7 \sim$ p. 14

[2] Louis J. Battan : Radar Meteorology (1959), The University of Chicago Press

[3]吉原善次：レーダー受信強度記録装置による降雨強度の観測， 気象研究時報, VII. 7 (1955) p. 439 p. 445

[4] 小平信彦：レーダーによる雨量観測 気象研究時報, VII. 7 (1955) p. 434 p. 438

[5]今井一郎他：雨のレーダ一反射因子と粒径分布について

気象研究時報, VII. 7 (1955) p. 422 p. 433

[6] Louis J. Battan : Radar Meteorology (1959), p. 51

[7] Louis J. Battan : Radar Meteorology (1959), p. 28, p. 30

[8] Louis J. Battan : Radar Meteorology (1959), p. 55

[9] 井関 貢 : 舶用 $3 \mathrm{~cm}$ レダーの小型船反射強度について（第 3 報）

日本航海学会誌 13 (1955) p. 43 p. 46

[10] 星 為蔵：風と波, 海の気象II, 12 (1957) p. 6

[11]［1]に同じ p. 13 